DOI

\author{
๑I. В. Каліновська
}

ВДНЗ України «Буковинсъкий державний медичний університет», Чернівиі

\title{
ЗМІНИ ІМУНОЛОГІЧНОГО СТАТУСУ ВАГІТНИХ ПРИ ПЛАЦЕНТАРНІЙ ДИСФУНКЦї̈
}

ЗМІНИ ІМУНОЛОГІЧНОГО СТАТУСУ ВАГІТНИХ ПРИ ПЛАЦЕНТАРНІЙ ДИСФУНКЦІї. У статті наведено резУЛЬтати змін імунологічного статусу вагітних при плацентарній фрормі фетоплацентарної недостатності. Показано збільшення рівня прозапальних IL-2 та зменшення рівня протизапальних IL-4, що призводить до порушень срункції ендотеліальних клітин судинної стінки, до судинного спазму та ішемії плаценти.

ИЗМЕНЕНИЯ ИММУНОЛОГИЧЕСКОГО СТАТУСА БЕРЕМЕННЫХ ПРИ ПЛАЦЕНТАРНОЙ ДИСФУНКЦИИ. В СТаТЬЕ приведены результаты изменений иммунологического статуса беременных при плацентарной фрорме фетоплацентарной недостаточности. Показано увеличение уровня провоспалительных IL-2 и уменьшение уровня противовоспалительных IL-4, который ведет к нарушениям фрункции эндотелиальных клеток сосудистой стенки, к сосудистому спазму и ишемии плаценты.

CHANGES OF IMMUNOLOGICAL STATUS OF PREGNANT WOMEN AT PLACENTA DYSFUNCTION. The article presents the results of changes of immunological status of pregnant women at the placenta form of fetoplacental insufficiency. The increase of level of inflammatory IL-2 and diminishing of level of inflammatory IL-4, which conduces the functions of endothelial cells of vascular to vascular spasm and ischemias of placenta.

Ключові слова: вагітні, фетоплацентарна недостатність, інтерлейкіни.

Ключевые слова: беременные, фетоплацентарная недостаточность, интерлейкины.

Key words: pregnant, fetoplacental insufficiency, interleukines.

ВстУП. Плацентарна недостатність є поширеним ускладненням гестації. Висока частота фретоплацентарної недостатності, перинатальна захворюваність і смертність вимагають подальшого вивчення патогенезу даної патології вагітності з метою пошуку ефективних методів ранньої діагностики, прогнозування, профрілактики і лікування цього ускладнення вагітності. В останні роки велику роль у розвитку фетоплацентарної недостатності відводять порушенню імунних взаємовідношень в системі мати-плацента-плід [1, 4].

Формування фретоплацентарних структур викликає суттєві зміни в імунокомпетентній сфері організму вагітних. Ці зміни спрямовані на забезпечення імунного захисту ембріона, надалі плода від агресії імунної системи матері $[2,3]$. Суттєву роль в імунних зв'язках гестаційного процесу відіграють цитокіни. Цитокіни - це білки, які виробляються переважно активованими клітинами імунної системи, позбавлені специфічності до антигенів іє медіаторами міжсистемних взаємодій та міжклітинних комунікацій при імунній відповіді $[4,5]$. У зв'язку з цим ми провели дослідження цитокінів у крові вагітних із плацентарною дисфрункцією [6].

Метою дослідження було вивчити зміни рівня прозапального IL-2 та протизапального IL-4 у сироватці крові вагітних із плацентарною диссункцією в терміні 36 до 40 тижнів вагітності.

МАТЕРІАЛИ ТА МЕТОДИ. Вагітні з проявами плацентарної недостатності в терміні 36 до 40 тижнів склали основну групу. Контрольну групу склали 80 здорових вагітних, без проявів явищ фоетоплацентарної недостатності, віком від 18 до 35 років. Вагітні основної та контрольної груп поділені на 4 підгрупи залежно від гестаційного терміну: до 8 тижнів вагітності (ранній ембріональний період), з 8 до 18 тижнів (ранній фетальний період), з 19 до 27 тижнів (II триместр вагітності), 328 до 40 тижнів (III триместр вагітності). Вік обстежених основної групи - від 18 до 35 років. Першовагітних було 53, повторновагітних - 67. Серед супутніх захворювань у вагітних основної групи в 27 \% спостерігалась анемія I ступеня, в $16 \%$ - дисрузний зоб I-ІІ ступеня, в $8 \%$ - вегетативна судинна дистонія за кардіальним типом. Рівень IL-2 та IL-4 визначали одноразово в кожній групі за допомогою реагентів «ProCon IL-2, IL-4», розроблених в НДІ морфрології людини РАМН.

РЕЗУЛЬТАТИ ДОСЛІДЖЕННЯ ТА ЇХ ОБГОВОРЕННЯ. У 30 вагітних (25\%) з 120 обстежених основної групи спостерігався десріцит IL-4 у сироватці, що в середньому складало 5,61 пг/мл. Це в 1,7 раза менше, ніж у контрольній групі, тоді, як рівень прозапального IL-2 зростав до 209,7 пг/мл. Цю підгрупу складали вагітні з явищами феетоплацентарної недостатності та синдромом затримки розвитку плода в III триместрі вагітності (3 28 до 40 тижнів).

Ретроспективний аналіз акушерського анамнезу показав, що в 17 жінок (54 \%) ранній ембріональний період вагітності супроводжувався кровомазаннями, частковим відшаруванням хоріона. У 27 жінок (90 \%) перша половина вагітності супроводжувалась явищами загрози переривання вагітності, у 10 жінок (33 \%) вже з 16 тижнів за даними УЗД виявлено ознаки фретоплацентарної недостатності. Всі 30 вагітних цієї підгрупи мали несприятливий результат у пологах: народили дітей з явищами затримки внутрішньоутробного розвитку (19 випадків - 63,3 \%), гіпотросрією (4 випадки - 13,3 \%), внутрішньоутробною гіпоксією (17 випадків - 56,6 \%). У вагітних контрольної групи (20 жінок у терміні 28-40 тижнів вагітності) показники рівня IL-2 та IL-4 були в межах норми і складали, 
відповідно, 90 та 7,66 пг/мл. При обстеженні вагітних із плацентарною дисфункцією в II триместрі (30 вагітних у терміні 19-27 тижнів вагітності) виявлено зниження рівня протизапального IL-4 до 3,45 пг/мл. У контрольній групі в 20 здорових вагітних в цьому терміні рівень IL-4 був у межах норми. Рівень прозапального IL-2 в даній підгрупі вагітних склав 99 пг/мл. В 30 вагітних основної групи в терміні від 8 до 18 тижнів вагітності (в ранньому фетальному періоді) рівень IL-4 коливався в межах 4,174,65 пг/мл. Тобто, спостерігається незначне зниження рівня IL-4 порівняно $з$ нормою, тоді як рівень IL-2 становить 46,5 пг/мл. У контрольній групі (20 вагітних) рівень IL-2, IL-4 був у межах норми. При дослідженні IL-2, IL-4 у вагітних основної групи в ранньому ембріональному періоді (до 8 тижнів вагітності - 30 жінок) виявлено різке зниження рівня IL-4 до 2,67 пг/мл, та збільшення рівня IL-2 до 239 пг/мл, а у випадках, де вагітність закінчилася мертвонародженням (в 7 \%) рівень IL-4 різко знижений до 0,91 пг/мл і надзвичайно високий рівень IL-2 (267 пг/мл).

Отримані результати досліджень показали, що сироватковий рівень IL-2, IL-4 є додатковим критерієм у діагностиці плацентарної дисорункції, а також прогностичним критерієм високого ризику перинатальних ускладнень. Високий рівень прозапального IL-2 (цитокінів Th I) та зниження рівня протизапальних IL-4 (цитокінів Th II) при плацентарній диссрункції в II та III триместрах вагітності призводить до пошкодження ендотелію, яке відбувається за рахунок активного впливу цитокінів на реакції системи гемостазу, зокрема на ендотеліальні клітини судинної стінки. Це викликає порушення проникності та фрункції капілярів ендотелію, в тому числі й судин плаценти. В умовах пошкодження ендотелію відбувається переважання продукції тромбоксану, що призводить до стійкого судинного спазму. На цьому фоні виникає ішемія клітин плаценти. Недостатність оретоплацентарної системи, яка виникає при цьому, призводить до хронічної гіпоксії плода і затримки його розвитку.

ВИСНОвок. Одним із основних фракторів розвитку фретоплацентарної недостатності $€$ зростання вмісту в крові прозапальних цитокінів (IL-2) і зменшення рівня протизапальних цитокінів (IL-4).

ПЕРСПЕКТИВИ ПОДАЛЬШИХ ДОСЛІДЖЕНЬ. В ПОдальшому планується вивчення зміни рівня імуноглобулінів у вагітних із проявами плацентарної диссрункції.

\section{СПИСОК ЛІТЕРАТУРИ}

1. Актуальні проблеми сучасної перинатології // В.І.Грищенко, М. О. Щербина, О. В. Мерцалова / Бук. мед. вісник. - 2001. - T. 1, № 2-3. - С. 3-7.

2. Демина Т. Н. Иммунологические аспекты синдрома задержки внутриутробного развития плода (обзор литературы) / Т. Н. Демина, С. А. Джеломанова // Медико-соціальні проблеми сім'ї. - 2011. - Т. 6, № 1. - С. 73-80.

3. Круть Ю. Я. Особенности имунных реакций в системе мать-плод при нормальной беременности (обзор) / Ю. Я. Круть, В. М. Шафрафрччук // Перинатологія та педіатрія. - 2013. - № 3. - C. 42-45.
4. Манасова Г. С. Нові аспекти патогенетичних механізмів фетоплацентарної недостатності / Г. С. Манасова, А. І. Гоженко, О. О. Зелінський // Одес. мед. журнал. - 2011. - № 4 (54). - C. 53-56.

5. Серов В. Н. Диагностика и терапия плацентарной недостаточности / В. Н. Серов // РМЖ. - 2012. - № 7. С. $34-37$.

6. Aberrations in placental cytokine mRNA related to intrauterine growth retardation / M. Hahn-Zoric, H. Hagberg, I. Kjellmer [et al.] // Pediatr. Res. - 2012. -Vol. 51, No.2. P. 201-206. 